\title{
The Influence of American Hegemony on Revolutionary thought
}

\author{
Kennedy-Jude Providence \\ University of Toronto \\ FAS Biology and Health and Disease/ Caribbean Studies
}

\section{A B S T R A C T}

In May 2020, two months after the COVID-19 pandemic struck the world, forcing humans stationary...at home...and unable to work and carry out routine, everyday activities, the brutal murder of George Floyd was captured on camera and broadcast on social media. Largely peaceful protests against police brutality and systemic racism erupted overnight, beginning in Minneapolis, and rapidly growing all over the United States. The Black Lives Matter (BLM) Movement's quickfire blaze continued to spread from Minneapolis all the way to the West Indies within a week. The longstanding relationship between the United States and the Caribbean region is evident, leading to the popularization of the regional idiom, "when the US sneezes, the Caribbean catches a cold." The impact of the BLM Movement on the Caribbean is comparable to that of the Civil

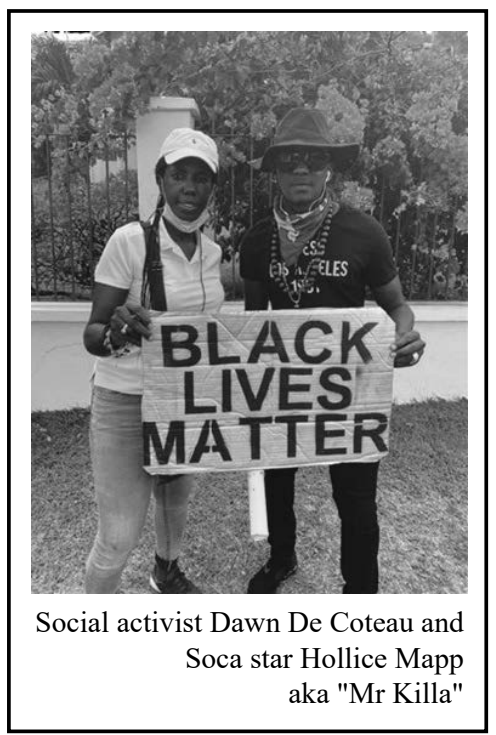
Rights and Pan Africanism movements of the latter half of the 20th century and reminds the world of the significance of regional revolutions such as the Grenada Revolution. One year into a crippling pandemic, the irony of this article will explore the aforementioned influences, comment on US intervention in Grenada and contextualize the adage- "When the US sneezes, the Caribbean catches a cold."

\section{B I O}

Kennedy Providence is a 4th year Biology, and Health and Disease double major, also pursuing a minor in Caribbean Studies. Having lived and grown up in the beautiful twin islands of Trinidad and Tobago, she studied the region's history and culture all throughout her pre-tertiary academic career.

(C) 2021 Kennedy-Jude Providence

Caribbean Studies Students'Union, Canada - https://jps.library.utoronto.ca/index.php/cquilt/ 
The regional idiom, "when the US sneezes, the Caribbean catches a cold" is profoundly multifaceted and compelling. The 'cold' can be interpreted in multiple ways, from the direct influence and impact on Caribbean lifestyle, fashion trends, food, culture and music by American hegemony, to influences in historic movements and revolutions. The United States of America has an infamous reputation of intervention, interference and intrusion in the governance and politics of Small Island Developing States (SIDS) and land territories within the Caribbean basin often fundamentally changing the trajectory of the Caribbean's revolutionary history. In 2020, this influence was seen, yet again, as the Black Lives Matter (BLM) Movement's quickfire blaze spread from Minneapolis on May 26, 2020 to the West Indies within a week. Largely peaceful protests against police brutality and systemic racism erupted in response to the deaths of Ahmaud Arbery, George Floyd and Breonna Taylor and the preceding generations of genocide faced by too many Black, Indigenous and other persons of colour within Uncle Sam's space. Considering the aforementioned influences and US intervention in Grenada this research seeks to consider some of the positive and negative externalities resulting from the region's proximity to US influence to contextualize the adage: "When the US sneezes, the Caribbean catches a cold."
The 2020 declaration of the COVID-19 pandemic initiated a wave of global lockdowns and everyday life stopped. Where physical or social distancing, quarantine, medical or fashion face masks, sanitizing formulae or frequent hand washing, strưctured coughing or sneezing and remote or virtual work and study became the new normal. Globally accepted social practices like handshakes and hugs were replaced by routine temperature checks and mass testing. As a result, human populations were driven to expónentially increased digital screen time and overall mass media consumption: virtual meetings, classes and gatherings were introduced, obsessive monitoring of news broadcasts for pandemic updates became routine. With increased media consumption and time at home, when the recorded murders of Ahmaud Arbery and George Floyd went viral on mainstream media, nations around the world sat up and paid attention. Unlike other făcets of society, the resulting protests benefited from "the COVID-19 domino effect" and its influence on the media.

With no pun intended, virtually overnight, everyone with access to cable television and the world wide web morphed into protestors, activists, bystanders or critics. Caribbean commentary of the 'rebellious and unruly' and sometimes violent nature of some protests, sought to isolate US 'sneezes' as not concerning the Caribbean, hinting that for the largely Afro-Caribbean population, racism and police brutality were not the norm. For the region

\footnotetext{
${ }^{1}$ Mendes-Franco, Janine. “'Born Fi Dead': The Caribbean Looks at the George Floyd Protests and Sees Itself.” Global Voices, 3 June 2020, globalvoices.org/2020/06/03/born-fi-dead-the-caribbean-looks-at-the-george-floydprotests-and-sees-itself/.
} 
however, "these ideals of togetherness and sentiments of being "one people" that are widely celebrated throughout island nations often overshadow deep rooted issues, which stem from the eras of slavery and colonialism." 2

Many Caribbean territories, not excluding Grenada, displayed an initial stance of solidarity with the BLM Movement, hosting island protests against systemic racism and police brutality. Grenadian activist Dawn De Coteau told Loop News Caribbean at a June 2020 BLM Protest, "the Caribbean must also face its own reality, as prejudices and racism exist in the Caribbean islands... when you look at the Black Lives Matter [movement in the region] it's about the social injustices, the economic injustices, health, equality, employment and about people from white communities parachuting into islands and demanding privilege." 3

Though the duration of the Caribbean BLM protests seemed to have been short-lived, and their overall impact incomparable to that of the US and larger countries, I believe that these demonstrations triggered in West Indians the prominence of revolution in Caribbean history. It reignited conversations about racism, colourism, discrimination and police brutality that have been left ignored since the independence and decolonization movements of the 1960s and 70s.
De Coteau's remarks on the BLM movement through a Grenadian lens, mirrored analogous sentiments shared by the former Prime Minister Maurice Bishop, who also aimed to advance and liberate Grenada during his dynamic 4-year stint in power. Bishop, along with the New Jewel Movement and the Grenadian public, had led a massive demonstration that resulted in the dismantling of preceding Prime Minister Eric Gairy's government. Achieving almost all of his goals, Bishop and the Grenada Revolution finalized the island's divorce from its European Colonial forefathers by attempting a 'popular Socialist' way of governance. Consequently, this put Grenada under a microscope operated by the United States which already had a special interest in the Spice-isle due to pre-existing relationships cultivated by Eric Gairy. Because of the ongoing Cold War with the Soviet Union, anyone or any country that showed agreement or interest in anything Marxist-Leninist or Socialist was swiftly blacklisted and kept under close watch by the USA

De Coteau's remarks on the BLM movement through a Grenadian lens, mirrored analogous sentiments shared by the former Prime Minister Maurice Bishop, who also aimed to advance and liberate Grenada during his dynamic 4-year stint in power. Bishop, along with the New Jewel Movement and the Grenadian public, had led a massive demonstration that resulted in the dismantling of preceding Prime Minister

\footnotetext{
${ }^{2}$ Noel, Melissa. "The Fight Against Racial Injustice Is A Caribbean Fight Too.” Essence, 1e7 July 2020, www.essence.com/feature/united-states-caribbean-relations-solidarity-protests/.

${ }^{3}$ Wong, Melissa. Grenadian Activist: Prejudices and Racism Exists in the Caribbean Too, 18 June 2020, www.loopnewscaribbean.com/content/grenadian-activist-prejudices-and-racism-exists-caribbean-too
} 
Eric Gairy's government. Achieving almost all of his goals, Bishop and the Grenada Revolution finalized the island's divorce from its European Colonial forefathers by attempting a 'popular Socialist' way of governance. Consequently, this put Grenada under a microscope operated by the United States which already had a special interest in the Spice-isle due to pre-existing relationships cultivated by Eric Gairy. Because of the ongoing Cold War with the Soviet Union, anyone or any country that showed agreement or interest in anything Marxist-Leninist or Socialist was swiftly blacklisted and kept under close watch by the USA.

Thus, when Socialist Cuba assisted Grenada in completing one of the major goals set out by Bishop, the surveillance being conducted by the US rapidly developed into a full invasion of the island. Under the pretence that Grenada's airport would be strategic for Soviet missions rather than tourism - and that another foothold in the region would be detrimental to the US, the 1983 Invasion of Grenada ultimately resulted in the assassination of Maurice Bishop and members of his Cabinet. If the US invasion of Grenada is examined in the context of the title of the article, the Invasion almost exactly justifies the statement "when the US sneezes, the Caribbean catches a cold". What began as the US involvement in the Cold War is equivalent to the "sneeze" and the neo-colonialist invasion Grenada suffered can be be read as the "cold". This tragic historic event is noteworthy as the US undermined a government with the help of spies and trampled upon past revolutionary successes by Caribbean peoples, leaving Grenada re-infected with another unforgettable Imperialist "cold".

As Mullin argues, the years following the 1983 invasion of Grenada have witnessed a continuation, and in many ways, deepening, of both: the racism that underpins the violent dispossession to which marginalized communities at 'home' and 'abroad' are subjected, coupled with the discursive infrastructure of a capitalist dominated media and public sphere designed to obscure and normalize this dispossession as well as to delegitimize resistance. ${ }^{4}$

Regardless of these negative influences, the region has experienced positive externalities resulting from its proximity to the US. The US heavily influenced the political and revolutionary climate of the region throughout the latter half of the 20th century, with the 1960's Civil Rights movement, Stonewall riots and Women's Liberation movement all leading to ripple effects in Caribbean politics. The African-American press played an important transnational role by reporting US. civil rights abuses to the world and by reporting African, and later, Caribbean and Latin American, independence and anti-colonialist struggles.

\footnotetext{
${ }^{4}$ Mullin, Corinna, and Azadeh Shahshahani. "To Organize in Times of Crisis, We Need to Connect the Dots of Global Resistance against Imperialism.” Uneven Earth, 18 Apr. 2020

${ }^{5}$ Lewis, Hope. "Globalization's People: Black Identities in U.S.-Caribbean Encounters." Law \& Inequality 32, no. 2 (2014): 349-.
} 
Various West Indian countries protested racism, colourism, the removal of an alien Head of State, along with other remnants of colonialism that stained the region. Unlike the BLM Movement, the Grenada Revolution, along with other movements endemic to the West Indies, did not model their demonstrations after those of their Northern Neighbours, but took advantage of the influential political atmosphere and implemented many inimitable riots and revolutions. As it relates to revolution, what we see in the Caribbean "is an original pattern, not European, not African, not a part of the American main, not native in any conceivable sense of that word, but West Indian, sui generis, with no parallel anywhere else." 6

Maurice Bishop did not draw inspiration directly from the US Civil Rights Movement and the Pan-Africanism movements; instead, he studied the leaders of these movements in depth, translated the issues being fought abroad to fit the Caribbean to evoke change. For Bishop, "there had not been any one single" point of influence. Rather, he "concentrated at one time his attention on Frantz Fanon, and on Malcolm X, Fidel, and Che, [as well as] Nkrumah and [...] many different socialist and progressive thinkers." ". As demonstrated in these examples of positive externalities, while United States "sneezes" may be the initial impetus for West Indian Movements, for a lasting impact, the leveraging of the Caribbean "original pattern" is needed. ${ }^{8}$ It is imperative that any revolution be bespoken to the region, related and implemented to suit each individual country.

While the 2020 BLM Movement achieved tremendous stimulation and awareness demanding justice for people of colour in the United States, its iterations in the region failed to successfully leverage Caribbean issues of inequality and racial injustice. It is important to note however that the tragedies captured on camera that fuelled the BLM Movement are not foreign or far-fetched in the Caribbean, and it is quite possible that after years of futile pleas for change falling on deaf ears, people have merely become desensitized to police brutality, violence, and racism. Just like the United States, the Caribbean "will only be able to truly realize the ideals of togetherness when conversations are had, and actions are taken to fully address racial inequities and discrimination".Perhaps there are still opportunities to embrace the political climate, revive our innate revolutionary spirit and lobby for level playing fields. It is yet to be seen when this revolutionary fight in the region may occur again.

\footnotetext{
${ }^{6}$ Lambert,Laurie. Comrade Sister: Caribbean Feminist Revisions of the Grenada Revolution. University of Virginia Press, 2020, pp. 3-4.

${ }^{7}$ Bishop, Maurice. "Revolution in Grenada: An Interview with Maurice Bishop.” The Black Scholar, vol. 11, no. 3, 1980, pp. 50-58.

${ }^{8}$ Lambert,Laurie. Comrade Sister: Caribbean Feminist Revisions of the Grenada Revolution. University of Virginia Press, 2020, pp. 3-4
} 


\section{Works Cited}

Wong, Melissa. Grenadian Activist: Prejudices and Racism Exists in the Caribbean Too, 18 June 2020, www.loopnewscaribbean.com/content/grenadian-activistprejudices-and-racism-exists-caribbean-too.

Noel, Melissa. "The Fight Against Racial Injustice Is A Caribbean Fight Too."

Essence, July 2020, www.essence.com/feature/united-states-caribbean-relationssolidarity-protests/.

Mendes-Franco, Janine. "'Born Fi Dead': The Caribbean Looks at the George Floyd Protests and Sees Itself." Global Voices, 3 June 2020, globalvoices.org/2020/06/03/born-fi-dead-the-caribbean-looks-at-the-georgefloyd-protests-and-sees-itself/.

Mullin, Corinna, and Azadeh Shahshahani. "To Organize in Times of Crisis, We Need to Connect the Dots of Global Resistance against Imperialism.” Uneven Earth, 18 Apr. 2020.

Lewis, Hope. "Globalization's People: Black Identities in U.S.-Caribbean Encounters." Law \& Inequality 32, no. 2 (2014): 349-.

Comrade Sister: Caribbean Feminist Revisions of the Grenada Revolution, by Laurie R. Lambert, University of Virginia Press, 2020, pp. 3-4.

Bishop, Maurice. "Revolution in Grenada: An Interview with Maurice Bishop." The Black Scholar, vol. 11, no. 3, 1980, pp. 50-58. 